\title{
Europeanization and regional cooperation initiatives: Austria's participation in the Salzburg Forum and in Central European Defence Cooperation
}

\author{
Patrick Müller ${ }^{1, *}$ \\ 1 Faculty of Social Sciences, University of the Basque Country (UPV/EHU)/ Leioa Campus, Bilbao, Spain \\ * E-Mail: patrick.muller@ehu.eus
}

\begin{abstract}
Multilateral cooperation schemes involving sub-sets of EU member states have proliferated over recent years. Yet, their implications for Europeanization research are little understood. Focusing on Austria's participation in the Salzburg Forum and in Central European Defence Cooperation, this article explores the implications of regional cooperation for Europeanization dynamics in the domains of internal and external security policy. On the one hand, it argues that multilateral cooperation schemes can function as a platform for policy-uploading and identifies important conditions that facilitate or impede the success of projecting national preferences through multilateral initiatives (vertical Europeanization). On the other hand, the article argues that multilateral cooperation schemes have led to the emergence of a web of loosely linked collaborative network structures that can facilitate the horizontal exchange of experiences and lessons learned beyond the boundaries of individual multilateral schemes (horizontal Europeanization).
\end{abstract}

\section{Keywords}

Austria, Europeanization, EU foreign policy, regional cooperation, Salzburg Forum, Central European Defence Cooperation

\section{Europäisierung und Regionale Kooperation: Österreichs Mitgliedschaft im Forum Salzburg und der Zentraleuropäischen Verteidigungskooperation}

\section{Zusammenfassung}

Multilaterale Kooperation mit Beteiligung einzelner EU Mitgliedstaaten hat sich in den letzten Jahren verstärkt, eine Entwicklung die von der Europäisierungs-Forschung bisher nicht hinreichend beachtet wurde. Dieser Artikel adressiert diese Forschungslücke. Untersucht werden zentrale Auswirkungen Österreichs Beteiligung an regionaler Kooperation - im Rahmen des Forum Salzburgs und der Zentraleuropäischen Verteidigungskooperation - auf die Europäisierung österreichischer Außen- und Sicherheitspolitik. Einerseits wird argumentiert, dass multilaterale Kooperation als eine Plattform zur Interessensdurchsetzung auf europäischer Ebene dienen kann (vertikale Europäisierung). Anderseits wird gezeigt, dass Formen multilaterale Kooperation zur Ausbildung von kooperativen Netzwerkstrukturen führen kann, die den horizontalen Austausch von Erfahrungen und 'Lessons-learned' unter EU Mitgliedstaaten befördern, ein Prozess der oftmals über die Grenzen von regionalen Kooperationsinitiativen hinaus wirkt.

\section{Schlüsselwörter}

Österreich, Europäisierung, EU Außenpolitik, Regionale Kooperation, Forum Salzburg, Zentraleuropäische Verteidigungskooperation

The author has declared that no competing interests exist. 


\section{Introduction}

Besides its membership in the European Union (EU), Austria is also an active participant in regional cooperation schemes that involve sub-groups of EU member states. Since the early 200os, Austria participates in the 'Salzburg Forum', which includes the Czech Republic, Hungary, Poland, Slovakia, and Slovenia. The objectives of the Salzburg Forum have evolved gradually over time and centre on regional cooperation on matters of internal security such as border control, police cooperation, and asylum; cooperation and joint lobby activities in the EU; and the implementation of a common foreign policy strategy on the Western Balkans. More recently, Austria has also become part of the Central European Defence Cooperation (CEDC). Established in $201 \mathrm{I}$ among Austria, Croatia, the Czech Republic, Hungary, Slovakia, and Slovenia, CEDC focuses on the development of security and defence capabilities and the coordination of defence policy and planning issues.

Although multilateral cooperation among sub-sets of EU member states plays an increasingly important role in the domain of internal and external security, the implications of these multilateral formats have thus far not systematically been addressed by Europeanization research. Research applying the Europeanization framework to the foreign policy domain has predominantly focused on the bi-directorial relations between the EU's Common Foreign and Security Policy (CFSP), the upper governance layer, and the national foreign policies of individual member states, representing the lower governance layer. This 'vertical' Europeanization perspective has also become commonplace in research on the Europeanization of different aspects of Justice and Home Affairs (JHA), the EU domain that corresponds with the policy agenda of the Salzburg Forum. At the same time, Europeanization research has identified horizontal exchanges between (individual) member states as an additional 'pathway' of Europeanization that involves the cross-loading of ideas, norms and ways of doing things. Building on this basic distinction that also informs the conceptual framework of this special issue (see introduction), this article explores the way Austria's involvement in (regional) cooperation schemes impact on the Europeanization of its internal and external security policies.

The ambition of this article is two-fold. First, it provides new empirical insights into Austria's participation in the frameworks of the Salzburg Forum and the CEDC, which have developed into an important element of Austria's internal and external security policies. With respect to theory, the article contributes to our understanding of the question how we can conceptualize and study the role of (regional) multilateral frameworks in Europeanization processes. The article proceeds as follows. It first briefly describes the state of the art of Europeanization research in the domains of foreign policy and JHA and proposes ways to conceptually integrate (regional) cooperation among sub-sets of
EU member states into Europeanization studies. On the one hand, it argues that multilateral cooperation schemes can function as a platform for uploading policy priorities to the EU level. On the other hand, multilateral cooperation schemes can facilitate the exchange of experiences and lessons learned beyond the boundaries of individual initiatives. Second, the chapter applies the conceptual framework to the study of Austria's involvement in the Salzburg Forum and in CEDC. The article shows that the Salzburg Forum triggered more significant Europeanization effects than CEDC, serving as a platform for coordinating joint positions and influencing EU policies, as well as a framework for exchanging lessons learned and policy learning. The conclusion highlights the main findings of the article, discussing key factors that may facilitate or impede Europeanization dynamics in the context of multilateral cooperation schemes.

\section{Europeanization of EU foreign policy and JHA: The neglected role of multilateral schemes}

It is commonly understood that Europeanization dynamics differ between more supranationalized policy fields such as JHA and intergovernmental fields like the EU's Common Foreign and Security Policy (CFSP) and its defence component, the Common Security and Defence Policy (CSDP) (see e.g. Featherstone/ Radaelli 2003, I52). Europeanization research thus needs to be sensitive to the specific institutional characteristics of various EU policies. This section will discuss Europeanization research in the domains of JHA and CFSP/CSDP one by one and introduces (regional) cooperation among sub-sets of EU member states as an important, yet not sufficiently understood, feature of Europeanization.

\subsection{Europeanization and justice and home affairs}

JHA has been one of the most dynamic areas of European integration, marked by the steady expansion of the scope of the policy and the progressive supranationalisation of the field. Starting out in the I970s as a loose form of intergovernmental cooperation among different groups of member states, the 1993 Maastricht Treaty incorporated the intergovernmental JHA domain into the treaty architecture of the EU. The Amsterdam Treaty of 1999 marked a next important step in the integration of JHA, incorporating sub-areas such as external border controls, asylum, immigration and civil law matters into the realm of the Community pillar. The Lisbon Treaty that entered into force in 2009 finally extended the Community method to all areas of JHA. Under the 
'Community method' the European Parliament plays the role as a co-legislator (through the ordinary legislative procedure), the Commission enjoys the exclusive right of legislative initiative (in few exceptional JHA matters this right is shared with a quarter of the member states) and the European Court of Justice (ECJ) has jurisdiction to enforce JHA decisions. Since the entry into force of the Lisbon Treaty, all but a limited number of JHA issues are, moreover, subject to qualified majority voting in the Council. ${ }^{1}$

The vertical understanding of Europeanization as a two-way process unfolding between the EU and the member states has also been prominently applied to the JHA domain (see e.g. Monar 2002; Menz 2011). Reflecting the multi-faceted character of the JHA domain that bundles several sub-areas research explored, among other things, the Europeanization of immigration and refugee policy (Lavenex 200I; Faist/Ette 2007; Menz 20II) the Europeanization of citizenship (Checkel 200I; Dell'Olio 2005; Vink 2002), and the Europeanization of anti-terrorism policy (Den Boer 2003). With the progressive institutionalisation of JHA, supranational institutions like the European Commission and the European Parliament have started to play an increasingly important role.

JHA has become subject to hierarchical governance with robust compliance mechanisms to make member states' governments conform to EU policies. Accordingly, top-down 'pressure' for policy implementation is substantially more pronounced than in intergovernmental domains like CFSP/CSDP, though compliance problems may still arise 'when public administrators, and economic and social actors, are not willing to bear the implementation burden' (Börzel 2002, 195). Still, in light of the growing constraints of EU law in the JHA domain, pro-actively shaping EU policy outcomes through 'policy uploading' becomes all the more important to reduce adaptation pressures. Importantly, the progressive extension of qualified majority voting in the Council to a growing number of JHA issue areas has increased the importance for coalition building and horizontal coordination among member states, to avoid being outvoted in the Council. While the use of majority voting is rare in the EU, which ususally tries to build a broad consensus, recent tensions over the migrant crisis have seen preference outliers outvoted, as it happened with Eastern European countries opposing an EU quota scheme for the relocation of migrants across the EU in September 2015 (see Financial Times 2015).

In addition to the incremental build-up of common EU level institutions more flexible forms of integration

I Key areas that stayed subject to unanimity voting in the Council (with the EP only being consulted) are: passport and identity cards, operational police cooperation, and family law. among subsets of member states have emerged, as captured in concepts such as 'flexible integration', 'differentiated integration', or 'Europe al la carte' (see Holzinger/ Schimmelfennig 20I2). Integration in the JHA domain has never been a uniform process. In important instances, integration involved the ex-post incorporation of initiatives that initially started outside the treaties into the EU. The Schengen cooperation establishing border-free areas constitutes a prominent example of such ex-post integration. Launched as an agreement between five EU member states in 1985 to facilitate the free movement of EU citizens it was later incorporated in the Amsterdam Treaty. Similarly, major aspects of the 2005 'Prüm Convention' on cross-border cooperation on issues such as combating terrorism, cross-border crime and illegal migration were later incorporated into EU legislation. While the Prüm convention was initially concluded among seven member states, cooperation on JHA related matters covered by the treaty was extended to all $\mathrm{EU}$ member states through a decision of the JHA Council in February 2007. At the same time, various formulas for 'opt-outs' and 'opt-ins' remain in place in this policy domain. ${ }^{2}$

Besides cooperation within the formal structures of the EU, bi- and multilateral groupings involving subsets of EU member states - and sometimes also including non-EU countries - have emerged often organizing on a geographical basis. While the prevalence of multilateral cooperation among sub-sets of EU member states is generally acknowledged in the relevant literature, its impact on Europeanization dynamics largely remains a research desideratum. In addition to the Salzburg Forum, this includes the Benelux countries, the Baltic Seas Task Force (the three Baltic states and Denmark, Finland, Germany, Iceland, Norway, Poland, Sweden, and Russia), the 'Visegrad group' (the Czech Republic, Hungary, Poland, and Slovakia), as well as the so called ' $G-6$ ' group (France, Germany, Italy, Spain and the United Kingdom and Poland). These multilateral groups not only differ in terms of membership and degree of institutionalisation, but also concerning the thematic scope of issues covered by multilateral cooperation. Whilst cooperation among Benelux countries or the Visegrad group extend to a broad range of policy areas and thematic issues - putting them in a good position for negotiating complex package deals at the EU level and broadens contacts among its members - the scope of the Salzburg Forum is narrower and within the EU focuses on the JHA domain.

2 On asylum, immigration and judicial co-operation Denmark has an opt-out while the UK and Ireland have an opt-in arrangement. With respect to Schengen, the UK and Ireland do not participate in the common border policy whilst Denmark only participates on an intergovernmental basis on the communitarized parts of the acquis. 


\subsection{Europeanization in the CFSP domain}

Given the intergovernmental character and sensitive nature of CFSP/CSDP, have led scholars to expect a limited impact of EU foreign and security policy on domestic policy choices (see Hix/Goetz 2000, 6). This view is reminiscent of the traditional distinction between 'high' and 'low politics', which expects strong member state resistance to compromising their sovereignty in the high politics domains of foreign and security policy Hoffmann (1966). Still, research on the Europeanization of national foreign policy has developed a growing academic profile since the 2000 (see Tonra 2015). The dominant understanding of Europeanization as an interactive process of change linking the national and EU levels has also become the prevailing view in the foreign policy domain (Tsardanidis/Stavridis 2005; Wong 2005; 2007; Major/Pomorska 2005; Alecu de Flers/Müller 2012). The CFSP provides member states with an instrument to achieve objectives that are difficult to obtain through national action. Here, the pooling of resources results in a 'politics of scale effect' (Ginsberg 1989), which increases the influence of EU member states' governments in world affairs and provides an incentive for member states to proactively project their preferences onto the EU level in a bottom-up direction.

At the same time, scholars pointed a number of voluntary processes such as reflexes for coordination and information sharing, elite socialisation, and reputation building through which participation in CFSP impacts on the member states national foreign policies in a topdown direction (see Smith 2004). ${ }^{3}$ Besides this vertical understanding of Europeanization as policy 'uploading' and 'downloading', scholars have also pointed to horizontal Europeanization dynamics that involve the 'cross-loading' of ideas, norms and ways of doing things (Major 2005, I68; see also Wong 2005). Studies on the horizontal pathway of Europeanization are few, however, which stands in contrast to the proliferation of Europeanization studies that explore the vertical interaction of member state and EU foreign policy. ${ }^{4}$

Simultaneously, as in the JHA domain the question how (regional) cooperation among sub-groups of member states impacts on foreign policy Europeanization, has thus far received little attention. This is surprising as multilateral cooperation initiatives involving sub-sets of member states also play an increasingly prominent role in the foreign policy domain. The EU Treaty accom-

3 All major decisions in CFSP require consensus among the member states in the Council, whilst the European Commission only plays a supportive role and other supranational actors like the European Parliament and the European Court of Justice enjoy only limited influence.

4 As Tonra (2015) points out, notable exceptions include works on the European Neighbourhood Policy (Normann 2012) and of Finnish foreign policy (Palosaari 201I). modates flexible forms of integration in CFSP/CSDP, with Denmark opting out of CSDP altogether. Moreover, groups of EU member states may establish 'enhanced cooperation' within established EU structures if certain conditions are met. Procedures for 'enhanced cooperation' are particularly elaborated in the domain of defence cooperation, with the Lisbon Treaty establishing three specific types for advancing cooperation among sub-sets of EU member states in CSDP (Art. 44-46 TEU). These procedures cover 'permanent structured cooperation' used for participating in military equipment programmes and for providing combat units for EU missions; cooperation on CSDP missions; and cooperation under the framework of the European Defence Agency (EDA).

Simultaneously, a number of multilateral collaborations involving subsets of EU member states have emerged outside formal $\mathrm{EU}$ structures, with varying ties to CFSP/CSDP. Multilateral groupings often are based on geographic or cultural proximity, mutual trust, and common concerns. Moreover, financial pressures resulting from the 2008 financial crisis amplified the need to realize synergies and scale effects through cooperation initiatives and burden sharing, particular in areas that require substantial financial resources like defence. As an observer has noted, cooperation among smaller groups of EU member states with similar preferences can help to realize efficiency gains whilst mitigating problems of decision making faced by the EU as a whole (see Mawdsley 2003). Since the outbreak of the financial crisis, defence cooperation has been reenergized in frameworks which have existed since the 1990s, including among the Benelux countries, the Baltic states, the "Weimar triangle' involving Poland, Germany and France, as well as the 'Visegrad group'. Simultaneously, new initiatives have emerged. In 2009 the Nordic countries Denmark, Finland, Iceland, Norway, and Sweden merged existing forms of defence cooperation into the comprehensive NORDEFCO framework (Nordic Defence Cooperation), in 2010 the UK and France signed the Lancaster House Treaties on bilateral defence cooperation and in 2012 Austria, Croatia, the Czech Republic, Hungary, Slovakia, and Slovenia formed the CEDC.

\subsection{Multilateral cooperation and Europeanization}

Multilateral frameworks for cooperation among subsets of EU member states can have important consequences for both vertical and horizontal Europeanisation dynamics. Concerning the vertical dimension of Europeanization, multilateral cooperation schemes may serve as a platform for influencing EU foreign policy outcomes through 'vertical' policy uploading. Member states participating in multilateral and regional cooperation schemes may pre-coordinate joint positions ahead 
of EU-level negotiations and pool their weight and resources to influence the outcome of negotiation processes. Here, 'multilateral' schemes can provide a more solid and long-term basis for interaction than ad-hoc practices of coordination and collation building among flexible groups of like-minded EU member states, which are frequently observed in Brussels (see Juncos and Pomorska 2006, 7). To establish the impact of multilateral cooperation schemes on 'policy uploading', this article relies on the following indicators:

- Practices/Style of Policy-Uploading: information sharing, pre-consultation and growing coordination on EU issues. Definition of common priorities and positions for the EU agenda.

- Policy Substance: degree to which common policy priorities and positions of a sub-set of EU member states involved in multilateral cooperation schemes are reflected in EU policy outcomes.

At the same time, multilateral cooperation schemes might even impact on EU policies if they are not deliberately designed as frameworks for lobbying EU policymaking. Relying on weakly institutionalised, informal frameworks for routine interactions among only a few countries - which often have similar interests and are characterized by geographic and cultural proximity - multilateral cooperation schemes provide fruitful settings for horizontal Europeanization dynamics. This involves the cross-national exchange of experience, lessons-drawing, and policy-transfer, whereby 'knowledge about policies, administrative arrangements or institutions is used across time or space in the development of policies, administrative arrangements and institutions elsewhere' (Stone I999, 5I).

While cross-loading can be expected to be most pronounced among those EU member states that are directly participating in a multilateral cooperation scheme, it may also involve other member states or even the EU as a whole. Importantly, member states outside a particular multilateral schemes may feel inclined to adopt similar 'policy solutions' and 'ways of doing things' if they become to view policies developed in multilateral settings as effective and/or legitimate solutions to address similar challenges. The Schengen regime could be described as a prominent case of 'example setting' where successful cooperation among a sub-set of EU member states later was extended to the $\mathrm{EU}$ as a whole. At the same time, multilateral cooperation schemes considerably overlap in membership and the scope of policies they cover; and sometimes individual schemes are also establishing cooperation between them. This produces a web of loosely connected and partly overlapping multilateral groupings, which facilitates the exchange of experiences and lessons learned across the boundaries of individual multilateral initiatives. Indicators for cross- loading dynamics in the context of multilateral cooperation schemes are:

- Practices/style of Policy Cross-loading: Establishment of mechanisms for policy coordination, joint experimentation and learning within multilateral schemes, as well as cooperation with other multilateral groups.

- Policy Substance: Degree to which joint objectives and policy solutions are adopted by the participants of multilateral schemes and beyond (e.g. by EU member states outside this multilateral framework).

\section{Austria and the Salzburg Forum - facilitating 'pragmatic Europeanization'}

To explore the role of the Salzburg Forum in the Europeanization of Austria's internal security policy, it is important to appreciate the growing relevance contributed to this regional initiative by Austrian officials. The Salzburg Forum constitutes the most important regional cooperation initiative for Austrian security policy and is specifically mentioned in Austria's security strategy as a key component of 'protecting the interests of Austria and Central Europe' (Bundeskanzleramt/BMEIA 20I3, I3). The Salzburg Forum developed out of an Austrian initiative to improve security in Central and Eastern Europe through regional cooperation with the five then $\mathrm{EU}$ candidate countries Slovakia, Slovenia, Czech Republic, Hungary and Poland in 2000. Romania and Bulgaria joined in 2006 and Croatia, after it had participated as an observer since 2006, became a full member in 2012.

The first conference among the interior ministers of the Salzburg Forum, who meet twice a year, took place in August 2000. While the Salzburg Forum has remained largely informal, certain working routines and principles have developed over time. Besides the six-monthly conferences, ad hoc meetings are organized at the margins of meetings of the EU JHA Council. Representatives from the EU Commission and from relevant EU agencies, such as the European Agency for the Management of Operational Cooperation at the External Borders (FRONTEX), the EU's law enforcement agency (Europol), the European Asylum Support Office (EASO), or the International Center for Migration Policy Development (ICMPD) are routinely invited for extensive discussions, which constitutes an important route for exchanging views with officials from EU institutions. The country holding the rotating presidency of the Salzburg Forum, moreover, keeps relevant EU level actors informed about important developments in the group. In the framework of the Salzburg Group, contacts of lower level bureaucrats have also intensified. Expert level meetings take place several times a year and national delegates at the permanent representations in Brussels meet on a regularly basis to discuss EU-level developments. Since the 
second half of 2004, official meetings are organized by the semi-annual presidency, rotating in alphabetical order among the participants, after they had initially been organized by Austria. The Salzburg Forum has, moreover, established a website and keeps a public record of its conclusions and decisions.

Uploading policies to the EU level: Initially, the main focus of the Salzburg Forum had been to prepare the accession countries for membership. With the EU's successful Eastern enlargement, however, the objective of jointly influencing EU JHA policies gained in importance. The Salzburg forum is very outspoken about its ambition to make a mark on EU policies, considering 'cooperation and lobbying within the EU' as one of its central functions (Salzburg Forum 2010: 4). With this end in mind, routine practices for consultation and policy coordination have developed. The Salzburg Forum commonly defines joint priorities for action at the EU level in its work programmes (I8 monthly) and its common statements. Moreover, the members of the Salzburg Forum consult each other and aim to coordinate their positions when preparing for EU-level meetings of the JHA Council, COREPER, and the Strategic Committee on Immigration, Frontiers and Asylum (SCIFA). Besides developing joint policy priorities, EU-level coordination has also involved the joint backing of candidates from member countries competing for EU positions in the field of JHA.

Progressive institutional reforms culminating in the Lisbon Treaty strengthened the formal capacity of the Salzburg Forum for policy uploading. Among other things, it allowed a quarter of the member states to present policy initiatives on criminal matters and police cooperation, enabling the Salzburg Forum to jointly initiate EU policies alongside the European Commission. As the group has noted:

'( $t$ )ogether, the Salzburg Forum states hold a total of 96 votes in the Justice and Home Affairs Council. This enables them to take an influence on EU decisions under the qualified majority voting regime and to draw attention to Salzburg Forum policies and ideas (Salzburg Forum 2015a).'

Yet, though the Salzburg Forum is intended to serve as a platform to influence EU policies, Austria has traditionally found it challenging to project its national preferences through this framework. A number of factors can be identified that limited Austria's capacity for policy uploading through joint action of the Salzburg Forum. Importantly, in the JHA domain the Salzburg Forum competes for influence with other multilateral formats including the Visegrad 4, the Benelux countries, the 'G-6' and the group of Baltic States. Bringing together powerful EU countries, the G-6 tends to play a particular prominent role in the JHA. This has also been felt by
Austria and its partners in the Salzburg Forum. In 2004, for instance, a plan to combat terrorism promoted by Austria - which invited the G-6 (then G-5) countries to a meeting with the Salzburg Forum - was viewed with scepticism by the G-6 and subsequently lacked support at the EU level (see Bossong 2007, 27).

At the same time, the Visegrad Group - which partly overlaps in membership with the Salzburg Forum - provides countries with membership in both groupings with an alternative regional framework for influencing EU policies (see also Kazmierkiewicz et al. 2006). Although Visegrad countries generally display considerable pragmatism when it comes to promoting their interests - relying on variable coalitions and frameworks - they also share important political, cultural and historic commonalities and have entered into cooperation and a wide array of issues, which sometimes pits them against Austria (see also Luif 2010). For instance, in 2007 Visegrad members successfully opposed the Austrian idea of postponing the date of their Schengen entry, exposing a rift between Austria and the Visegrad countries (Visegrad Group 2015). The fact that Austria cooperates in the Salzburg forum with countries that are closer to each other politically, culturally, and historically than they are to Austria has long been identified as a central challenge for Austria's regional ambitions (see Kiss, Königova and Luif 2003, 58).

Still, though cooperation in the Salzburg Group evidently poses challenges for Austria, this does not mean that the group is not capable of joint action. For all their differences, the members of the Salzburg Group share a similar geopolitical location, which exposes them to similar (security) challenges and creates a clear rationale for regional cooperation. With the exception of Poland, members of the Salzburg Forum are, moreover, relatively small in size, providing an incentive to build (durable) coalitions with other member states. On issues on which the members Salzburg Forum could agree, the group has become recognized as a relevant actor in the JHA domain, which also benefited Austria. Among other things, the Salzburg Forum actively contributed to the development of important aspects of the EU's 2010 'Internal Security Strategy' (see Sandrisser 2012, 535). Austria and its partners in the Salzburg Forum have also jointly worked on issues concerning cooperation in the Schengen area. Among other things, the Salzburg Forum has defended the ability of Schengen countries to temporarily reintroduce controls at internal borders if public order and internal security are seriously threatened. In a joint declaration of June 20II, the ministers of the Salzburg Forum agreed that a mechanism of gradual measures should be established to respond to exceptional circumstances putting the overall functioning of Schengen at risk' - including the reintroduction of border controls as a last resort. In pursuit of this objective, 
Austria not only sought to win the support of the Salzburg Forum, but in parallel also tried to build a coalition with Germany, the Netherlands and France. A response mechanism for exceptional circumstances was finally agreed among EU countries in June 2012 at a ministerial meeting in Luxembourg.

This shows that building coalitions with other actors and groupings outside the Salzburg Forum can produce a real added value, if such parallel strategies for cooperation serve a common purpose. Austria's efforts to influence the EU's policy on the fight against illegal migration and trafficking in human beings - which affects Austria both as a transit and a destination countryfurther illustrates this point (BMEIA 2015). To promote the fight against illegal migration at the EU level, Austria tried to win the backing from the Salzburg Forum as well as from like-minded EU countries such as Germany, the Netherlands, France, Sweden, the UK and Belgium (Die Presse 20I2). This alliance of like-minded countries subsequently played an important role in initiating an EU action plan on fighting illegal migration (European Council 20I2), which was adopted by the Council in April 2012 (Council of the European Union 20I2).

More recently, the Salzburg Forum has also served as a platform to influence EU level debates on 'Strategic Guidelines' for JHA, which were approved by the Council in June 20I4. Proposed by the Lisbon Treaty, the Strategic Guidelines provide for legislative and operational planning on aspects such as border control, migration, asylum policy, and police and judicial cooperation. While the members of the Salzburg Forum expressed their discontent about not having had the opportunity to directly participate in the drafting process of the guidelines, the group still positively noted that:

'numerous of the joint positions of the Salzburg Forum agreed upon in late 2013 under the auspices of the Romanian presidency have featured prominently in the summaries of debates and have also received support from other member states' (Salzburg Forum 20I4).

Against the backdrop of the intensifying migrant crisis faced by the EU, recent efforts of the Salzburg Forum have focused on cooperation on the Western Balkan that has become an important transit route for migrants and asylum seekers. Here, the Salzburg Forum could draw on its ongoing cooperation with Western Balkan countries in the framework of the so-called 'Group of Friends of the Salzburg Forum'. Established in 2007, the Group of Friends involves routine meetings with the aim to enhance the internal security in Central and South-Eastern Europe and to fight common threats such as cross-border organized crime, corruption and illegal migration (Salzburg Forum 2015b). Among other things, the Salzburg Forum agreed on the need to develop an 'Alliance against Illegal Migration in Central and SouthEast Europe' that should build on existing platforms and initiatives as well as on the capabilities of the European Asylum Support Office (EASO), Frontex, and the United Nations High Commissioner for Refugees (UNHCR). Yet, these efforts came at a time when tensions among member states over dealing with the recent migrant and refugee crisis had severely intensified among members of the Salzburg Forum, making joint action on the basis of common interests increasingly challenging.

Horizontal Europeanization Effects: Besides serving as a framework for influencing EU level policy outcomes, regional cooperation among the members constitutes another important pillar of the Salzburg Forum. Importantly, the Salzburg Forum has established a 'security partnership' that involves regional police cooperation as well as regional cooperation on border control, fighting the trafficking of people, and asylum as well as the exchange of opinions on particular EU matters (Salzburg Forum 200I). Over time, expert working groups have been established that cover key priority areas of regional cooperation, including on issues such as cross border traffic cooperation, witness protection and DNA data exchange. In July 2007, the Salzburg Forum, moreover, agreed to develop a Central European Operational Network (CEON) that includes common police centres, joint patrols in border areas and the exchange of liaison officers. Members have seconded liaison offers, set up joint police cooperation centres at their internal borders and carried out joint patrols in border regions (Salzburg Forum 20IO). As pointed out by an observer, this horizontal cooperation creates space for 'elaboration and testing, in a smaller context of like-minded states or contiguous neighbours, of measures that can subsequently be exported to all member states' (Lavenex 20I0, 467).

Not only has the Salzburg Forum developed collaborative structures for the exchange of information, personnel and lessons learned among its members, it also sought to deepen institutional cooperation with other regional/multilateral cooperation structures within the EU. In its 'vision 2020' the Salzburg Forum has committed itself to developing regular relations to frameworks such as the G-6, the Baltic and Nordic cooperation structures and the Benelux group. While cooperation with multilateral groups provides a channel for horizontal exchange beyond the Salzburg Forum, in practice such cooperation has made little progress. Rather, it is primarily through institutional overlap - particularly with the Visegrad group, which has close ties with the group of Benelux and Nordic countries, as well as with the G-6, where Poland is a member - that the Salzburg Forum links up with other regional cooperation schemes.

Based on the above established indicators, it thus can be said that the forum Salzburg at present still impacts 
on the EU's JHA domain mainly through the 'uploading' of joint policies. The members of the Salzburg group explicitly aim at influencing EU level policy outcomes and have developed specific coordination practices for that aim. Though the conditions for uploading joint policies to the EU level are demanding, important instances have been identified where Austria and its partners in the Salzburg Forum have been successful in shaping EU policy outcomes. Horizontal cooperation among the members of the Salzburg Forum, in turn, is only gradually producing concrete policy outcomes and it remains to be seen whether policy solutions and lessons learned in this framework will travel also beyond the Salzburg group.

\section{Central European Defence Cooperation: No major Europeanization effects (yet)}

CEDC dates back to a conference on 'security cooperation in central Europe' organised by the Austrian defence ministry in cooperation with the Austrian Defence Academy in May 2010 (see Bachora 2013, 93). It includes Austria and its central European partner countries Croatia, Czech Republic, Hungary, Slovakia, and Slovenia and covers cooperation in the sensitive domain of defence, where member states have traditionally been very reluctant to transfer sovereignty to the EU. Specifically, it focuses on the development of security and defence capabilities and the coordination of the member countries' views on defence policy and planning issues. Poland - which is already part of the 'Weimar Triangle' and the 'Visegrad Group' - opted for observer status in CEDC. Besides Austria, which is cooperating with NATO through the 'partnership for peace' framework, all CEDC countries are members of the transatlantic alliance.

Austria has been a major supporter of CEDC, following up on unsuccessful earlier efforts to facilitate defence cooperation with its Central European neighbours. The first meeting of CEDC defence ministers took place in the small Austrian town of Frauenkirchen in June 2012. The meeting focused on deepening coordination and cooperation on military and security matters among the participants, identifying key technical areas for future cooperation including cooperation on the training of Special Forces, on chemical, biological, radiological, and nuclear (CBRN) defence, as well as on participation in international peace missions. Cooperation within CEDC proceeds 'a la carte', with different participants may forming varying clusters of cooperation in smaller groups (Kurowska and Németh 2013, 2). Different countries may take the lead in proposing new initiatives and food for thought papers. Meetings at the level of political directors usually take place at the margin of EU, NATO and Visegrad meetings, whilst expert workshops involving lower level officials have taken place more fre- quently in the areas earmarked for cooperation within CEDC. After a 'pilot phase' that lasted about three years, the members of CEDC agreed on a number of steps towards a 'light' institutionalisation of their cooperation. In May 2015 the defence ministers of CEDC countries issued a joint declaration in Brdo, Slovenia, proposing a yearly rotating presidency; clear responsibilities for the covered themes; and regular meetings at different levels.

Policy uploading: In contrast to the Salzburg Group, cooperation within CEDC does not have an explicit focus on influencing EU-level policy outcomes, but aims at bringing a real value added to both CSDP and to NATO by assisting cooperation efforts undertaken in these frameworks. While CEDC countries generally consider their multilateral cooperation as complementary to CSDP and routinely inform EU officials about the state of their multilateral efforts (see e.g. Visegrad Group/ Ministry of Defence of Hungary 20I4), their ambitions to influence EU-level decision-making and to contribute to joint EU activities have thus far remained modest. ${ }^{5} \mathrm{As}$ stated by an Austrian military official based in Brussels, coordination of CEDC countries prior to EU level negotiations are not very frequent and ad hoc and mainly concern the Western Balkan, including issues related to the EUFOR ALTHEA mission in Bosnia. ${ }^{6}$ The Ukraine crisis has also developed into an urgent matter in the CEDC framework, yet, discussion among CEDC members have not produced major common initiatives. On most issues, Austria and other CEDC members pursue their interests through flexible coalitions with like-minded countries. According to Austrian officials, in particular Austria shares important commonalities and interests with the other neutral EU member states Finland, Sweden and Ireland as well as geographic and cultural neighbours like Germany, with whom it shares a common language. ${ }^{7}$ Moreover, the fact that CEDC overlaps considerably in its membership and its policy agenda with the older, more coherent and more developed 'Visegrad Group' evidently makes it difficult for CEDC to develop a strong independent profile. Thus far, it thus appears that CEDC lacks the ambition and internal cohesion to function as a platform for the projection of national preferences to the EU.

Horizontal exchange: CEDC's role as a framework for regional cooperation has been more significant than its role in facilitating EU level initiatives. CEDC has produced a number of concrete projects and actions among its participants. Though a number of CEDC projects have been carried out in the framework of NATO's

5 Interview with a member of the Austrian Ministry of Defence and Sports placed in the Büro für Sicherheitspolitik, Vienna, 2 February 2015 .

6 Interview with an Austrian military representative to the European Union Military Committee in Brussels, 30. June 2015.

7 Interview with an Austrian representative to the European Union's Political and Security Committee in Brussels, 27. August 2015. 
'smart defence', such activities might also provide benefits for CSDP, particularly since NATO and the EU make increasing efforts to ensure complementary in capability development. Collaborations developed in the CEDC framework include the following projects:

- On a Czech initiative, CEDC countries have engaged in expert talks on cooperating in the field of chemical, biological, radiological, and nuclear (CBRN) defence. This involves information sharing and exchange on $\mathrm{CBRN}$ defence and assessing possibilities for joint training programmes.

- Austria and Croatia have engaged in bilateral cooperation in the field of training Special Operations Forces (SOF), which might at a later point be extended to other CEDC countries.

- A multinational logistic co-ordination centre has been established in the Czech Republic in 2010 and an initiative to create a multinational Joint Logistics Support Group (JLSG) was put forward.

- The Czech Republic, Croatia and Hungary have engaged in joint training activities for air mentor teams for Afghanistan.

- Hungary has launched an initiative on cooperation on Counter Improvised Explosive Devices (C-IED).

Another important issue discussed among CEDC countries is regional air patrolling. Lacking the capabilities to police its airspace in accordance with NATO standards, Slovenia has long relied on the services of Italy, recently joined by the Hungarian air force, for policing its airspace (The Slovenia Times 2014). Against the backdrop of severe cuts in its defence budget Austria has, furthermore, started internal discussion on options to develop cooperation on air policing with neighbouring countries, particularly with Hungary. However, raising intricate (legal) questions concerning its neutrality, no concrete steps have (yet) been taken in this direction. At the same time, discussions have intensified on cross-border cooperation on responding to natural disasters, including support through military units such as the Austrian Forces Disaster Relief Unit, as well as on the cooperation of Special Forces (Fronek and Logothetti 2014).

Thus far, it can be said that regional cooperation in the CEDC framework is just gradually developing and has not (yet) produced discernible effects beyond the group. As a non-NATO country Austria, moreover, often feels excluded from discussions and informationsharing among NATO members - both within the CEDC framework and within CSDP. In this respect, Austrian officials do not feel that membership in CEDC has improved their access to privileged information and technologies obtained by CEDC partners that are also part of the transatlantic alliance. Yet, CEDC is still a young initiative and cooperation in defence is notoriously difficult, so it might require more time and sustained efforts for CEDC to produce wider Europeanization effects.

\section{Conclusion}

Austria's participation in the Salzburg Group and the CEDC initiative provides interesting new insights into the way how such multilateral schemes may contribute to vertical and horizontal Europeanization dynamics. Concerning 'vertical Europeanization', Austria's involvement in the Salzburg Forum shows that regional cooperation schemes can provide a useful platform for coordinating joint positions to influence EU policies. As insights from theoretical works on small states in international relations tells us, forging alliances is a common tactic for smaller, or medium sized countries like Austria to compensate for a lack of domestic resources and capabilities. Austria has successfully worked through the Salzburg framework to influence EU policies on issues such as the EU's 2OIO Internal Security Strategy, the establishment of a response mechanism for exceptional circumstances met by the Schengen area in 2012, and the EU's 2015 Strategic Guidelines for JHA. The growing supranationalization of the JHA domain provides a strong incentive for joint action through the Salzburg Forum, as individual countries can no longer unilaterally resist unfavourable policies at the EU level. Here, the failure to shape EU-level policy outcomes can result in high adaptation costs in the implementation phase.

At the same time the conditions for projecting national preferences through multilateral frameworks like the Salzburg Forum are demanding. Despite some notable instance of Austrian influence on EU policies through the Salzburg framework, overall its capacity to use multilateral cooperation schemes for the projection of national preferences has been rather limited. First, the constellation of preferences of the members of multilateral cooperation schemes matters. Lacking a strong sense of collective regional identity, the Salzburg Forum largely operates on the basis of common interests. Only if the interests of its members coincide can the Salzburg Forum provide a useful means for exercising EU level influence. Here, overlapping membership with other (regional) schemes, particularly with Visegrad, can represent an additional challenge in situations where Visegrad countries give preference to act through the Visegard framework rather than through the Salzburg Forum. Still, even in situations where the Salzburg Forum acts jointly influencing policymaking at the EU level remains a difficult undertaking. Influencing EU policy outcomes requires forging alliances beyond the Salzburg group, which competes for influence with powerful groupings and larger member states. What is more, the experience of CEDC shows that regional groups may lack a clear 
ambition to influence EU level policy outcomes in the first place, with CEDC focusing on complementing and assisting, rather than shaping, EU policies.

Moreover, both its experiences in the Salzburg Forum and in the framework of CEDC testify of Austria's challenge to collaborate with partner countries that in many respects have closer and more developed political, cultural, and historic ties with each other than with Austria. Whilst committed to cooperation in Central Europe, Austria can easily find itself isolated in such an environment. At the same time, Austria shares itself important commonalities with other EU countries outside the Salzburg Forum and CEDC, such as the neutral EU member states Finland, Sweden and Ireland as well as geographic and cultural neighbours like Germany. Against this backdrop, Austria has maintained a rather pragmatic attitude towards cooperation in the Salzburg Forum and in the CEDC framework, often perusing its preferences through multiple alliances. This is also true for most of Austria's partners in the Salzburg Forum and CEDC. Given that both the Salzburg Forum and CEDC aim to complement and assist EU level activities, rather than to compete with them, it is moreover important to note that participation in these forums tends to advance Austria's standing in the EU, rather than undermining its commitment to EU level cooperation.

While this article points to important factors that can facilitate and impede policy up-loading through multilateral forums, further comparative research is necessary for a more systematic testing of these findings. Besides providing a platform for policy uploading, multilateral groups also constitute fruitful venues for horizontal coordination. Austria's participation in the Salzburg Forum and CEDC shows that horizontal coordination is often underpinned by the development of a collaborative network structure, including the set-up of joint operational centres, the exchange of personal, information and experiences, and joint programmes and operational action. Austria's involvement in such collaborative projects has already translated into growing horizontal exchanges and cross-border cooperation with its partners in the Salzburg Forum and CEDC. At the same time, the proliferation of multilateral schemes - which overlap in their membership and policy agendas and have established varying degrees of cooperation between them - has resulted into a web of loosely connected multilateral groupings, which may will also facilitate the exchange of experiences and lessons learned across the boundaries of individual schemes. This raises interesting new research questions, e.g. about the way how cooperation between the Salzburg forum and Visegrad impacts positions taken in these different forums. At a more general level, studying the broader picture of the emerging links between different multilateral cooperation schemes beyond the Salzburg Group and CEDC constitutes a fascinating agenda for future research that speaks directly to the theme of horizontal Europeanization.

\section{Literature}

Alecu de Flers, Nicole/Patrick Müller (2012). Dimensions and Mechanisms of the Europeanization of Member State Foreign Policy: State of the Art and New Research Avenues, in: Journal of European Integration, Vol. 34(I), I9-35.

BMEIA (2015). Combating Trafficking in Human Beings, Website of the Bundesministerium für Europa, Integration und Äußeres. Internet: http://www.bmeia. gv.at/en/european-foreign-policy/human-rights/ priorities-of-austrian-human-rights-policy/combatting-trafficking-in-human-beings/ (accessed: I2.II.2OI2).

Bachora, Ratislav (20I3). Militärkooperationen in Zentraleuropa - Ableitung für die Central European Defence Cooperation aus österreichischer Sicht, in: Johann Frank/Wolfgang Braumandl-Djurdin (eds.): Parameter europäischer Sicherheit: Die GSVP zwischen Strategischer Herausforderung und Nationalstaatlicher Räson, Vienna.

Börzel, Tanja (2002). Pace-Setting, Foot-Dragging, and Fence-Sitting: Member State Responses to Europeanization, in: Journal of Common Market Studies, Vol. 4O(2), I93-2I4.

Bossong, Raphael (2007). The European Security Vanguard? Prüm, Heiligendamm and Flexible Integration Theory, LSE Working Paper January, London.

Bundeskanzleramt/BMEIA (20I3). Austrian Security Strategy: Security in a New Decade - Shaping Security, Vienna.

Checkel, Jeffrey (200I). The Europeanization of Citizenship?, in: Maria Green Cowles/James A. Caporaso/ Thomas Risse-Kappen (eds.): Transforming Europe: Europeanization and Domestic Change, Ithaca, I8097.

Dell'Olio, Fiorella (2005). The Europeanization of Citizenship: Between the Ideology of Nationality, Immigration, and European Identity, Aldershot.

Den Boer, Monica (2003). 9/II and the Europeanization of Anti-Terrorism Policy: A Critical Assessment, Groupement D'Etudes Et De Recherches - Policy Papers No.6, Notre Europe, September 2003. Internet: https://infoeuropa.eurocid.pt/files/database/ooooo500I-00ooloooo/ooooo7639.pdf (accessed: I2.II.2OI5). 
Die Presse (2012). Illegale Migration: Jetzt werden Nägel mit Köpfen gemacht, 26. April 2012. Internet: http:// diepresse.com/home/politik/eu/752679/IllegaleMigration_Naegel-mit-Kopfen-gemacht (accessed: I2.II.2O15).

Die Welt (2015). Auf dem Balkan braut sich etwas zusammen, I9 August 2015. Internet: http://www.welt. de/politik/ausland/articleI4659I62I/Auf-dem-Balkan-braut-sich-etwas-zusammen.html (accessed: I2.II.2OI5).

Council of the European Union (2012). EU Action on Migratory Pressure - a Strategic Response, 23 April 2012, Brussels.

Featherstone, Kevin/Claudio M. Radaelli (2003). The Politics of Europeanization, Oxford.

Faist, Thomas/Andreas Ette (eds.) (2007). The Europeanization of National Immigration Policies: Between Autonomy and the European Union. London.

Financial Times (2015). EU Ministers Force through Refugee Quota Plans, 22. September 2015. Internet: http://www.ft.com/intl/cms/s/o/76c2ddge-6III-IIe59846-de406ccb37f2.html\#axzz3rIIIJyLi (accessed: I2.II.2OI5).

Fronek, Thomas/Rudolf Logothetti (2014). Sicherheitspolitische Konsultationsgespräche Österreich - Kroatien. Der Soldat, Unabhängige Zeitung für Wehrund Sicherheitspolitik, No. I4, 23.

Ginsberg, Roy H. (1989). Foreign Policy Actions of the European Community - The Politics of Scale, Boulder.

Hix, Simon/Klaus H. Goetz (200o). Introduction: European Integration and Parliamentary Government, in: West European Politics, Vol. 23(4), I42-168.

Hoffmann, Stanley (1966). Obstinate or Obsolete? The Fate of the Nation-State and the Case of Western Europe, in: Daedalus, Vol. 95(3), 862-915.

Holzinger, Katharina/Frank Schimmelfennig (2012). Differentiated Integration in the European Union: Many Concepts, Sparse Theory, Few Data, in: Journal of European Public Policy, Vol. I9(2), 292-305.

Juncos, Ana/Karolina Pomorska (2006). Playing the Brussels Game: Strategic Socialisation in the CFSP Council Working Groups, European Integration Online Papers, Vol. IO(II).

Kazmierkiewicz, Piotry/Dóra Husz/Juraj Misnia/Ivo Slosarcik (2006). The Visegrad States on the EU's Eastern Frontier. Conculsar and Visa Cooperation in East Central Europe for Residents of Ukraine and Moldova. Center for Policy Studies, Central European University, Budapest.

Kiss, Lázló/Lucie Königova/Paul Luif (2003). Die 'Regionale Partnerschaft': Subregionale Zusammenarbeit in der Mitte Europas, in: Österreichische Zeitschrift für Politikwissenschaft, Vol. 32(I), 57-75.
Kurosawa, Xymena/Bence Németh (2013). A Playground in Central Europe: Who Plays What? European Geostrategy, Longposts, 22 May 20I3. Internet: http:// www.europeangeostrategy.org/2013/o5/playgroundcentral-europe/ (accessed on: 27.0I.2015).

Lavenex, Sandra (200I). The Europeanization of Refugee Policies: Normative Challenges and Institutional Legacies, in: Journal of Common Market Studies, Vol. 39(5), 85I-874.

Lavenex, Sandra (2010). Justice and Home Affairs: Communitarization with Hesitation, in: Helen S. Wallace/ Mark A. Pollack/Alasdair R. Young (eds.): Policymaking in the European Union, Oxford, 457-48I.

Luif, Paul (2010). Austria and Central Europe, Perspectives, in: Review of International Affairs, Vol. I8(2), 95-IO9.

Major, Claudia (2005). Europeanization and Foreign and Security Policy: Undermining or Rescuing the Nation State?, in: Politics, Vol. 25(3), 175-190.

Major, Claudia/Karolina Pomorska (2005). Europeanization: Framework or Fashion?, CFSP Forum, Vol. 3(5), I-4.

Mawdsley, Jocelyn (2003). Arms, agencies, and accountability: the case of OCCAR, in: European Security, Vol. I7(3), 367-85.

Menz, Georg (201I). Stopping, Shaping and Moulding Europe: Two-Level Games, Non-state Actors and the Europeanization of Migration Policies, in: Journal of Common Market Studies, Vol. 49(2), 437-462.

Monar, Jörg (2002). The Dynamics of Justice and Home Affairs: Laboratories, Driving Factors and Costs, in: Journal of Common Market Studies, Vol. 39(4), 747764 .

Monar, Jörg (2003). Justice and Home Affairs as a Government Controlled Process, in: Kenneth Dyson/ Klaus Goetz (eds.): Germany, Europe, and the Politics of Constraint, Oxford, 309-323.

Normann, Christine (2012). Analysing the Evolution of the European Neighbourhood Policy: Theoretical and Methodological Triangulation, in: Edmund Radka/Olga Spaiser (eds.): Understanding European Neighbourhood Policies, Baden-Baden, 53-69.

Palosaari, Temo (20II). The Art of Adaptation: a Study on the Europeanization of Finland's Foreign and Security Policy, TAPRI Studies in Peace and Conflict Research No. 96/201I, Tampere.

Salzburg Forum (200I). Joint Declarations by the Ministers of the Interior of the Republic of Austria, the Czech Republic, the Republic of Hungary, the Republic of Poland, the Republic of Slovakia and the Republic of Slovenia, Salzburg, July 26-28 200I. Internet: http:// www.salzburgforum.org/presdoc/Joint_Declaration_Salzburg_July\%2026-28_\%2O2O0I_Unofficial_Translation.pdf (accessed: I2.II.2OI5). 
Salzburg Forum (2010). Salzburg Forum Vision 2020, Consolidated Version, 24 August 20I0. Internet: http://www.salzburgforum.org/presdoc/Salzburg \%2OForum\%2OVision\%2O2O2O.pdf (accessed: I2.II. 2015).

Salzburg Forum (2014). Joint Declaration, Salzburg Forum Ministerial Conference, Modra, I9 June 20I4, Internet: http://www.salzburgforum.org/presdoc/Declaration \%20Ministerial\%20Conference \% 20in \% 20 Modra.pdf (accessed: I2.II.2OI5).

Salzburg Forum (2015a). About Us. Website of the Salzburg Forum, Internet: http://www.salzburgforum.org/site/ aboutus.html (accessed: I2.II.2OI5).

Salzburg Forum (2015b). External Relations. Website of the Salzburg Forum, Internet: http:/www.salzburgforum.org/site/extrel.html (accessed: I2.II.2OI5).

Sandrisser, Wilhelm (2012). Innere Sicherheit neu Denken: Herausforderungen und Gestaltungsmöglichkeiten für Österreich, in: Johann Frank/Walter Matyas (eds.): Strategie und Sicherheit, Vienna, 527-542.

Smith, Michael E. (2004). Europe's Foreign and Security Policy: The Institutionalisation of Cooperation, Cambridge.

The Slovenia Times (2014). Hungarian Fighters Policing Slovenian Airspace, I7 January 20I4, Internet: http:// www.sloveniatimes.com/hungarian-fighters-policing-slovenian-airspace (accessed: I2.II.2OI5).

Stone, Diane (1999). Learning Lessons and Transferring Policy Across Time, Space and Disciplines, in: Politics, Vol. I9(I), 5I-59.

Tonra, Ben (2015). Europeanization, in Knud Erik Jorgensen/Aasne Kalland Aarstad/ Edith Drieskens/Katie Laatikainen/Ben Tonra (eds.): The SAGE Handbook on European Foreign Policy, London, I83-I97.

Tsardanidis, Charalambos/Stelios Stavridis (2005). The Europeanization of Greek Foreign Policy: a Critical Appraisal, in: Journal of European Integration, Vol. 27(2), 217-239.

Vink, Maarten (2002). The Limited Europeanization of Domestic Citizenship Policy: Evidence from the Netherlands, in: Journal of Common Market Studies, Vol. 39(5), 875-896.

Visegrad Group/Ministry of Defence (2014). Letter to the High Representative of the European Union for Foreign Affairs and Security Policy, 9. April 2014.

Visegrad Group (2015). Visegrad - Arrival, Survival, Revival, Website of the Visegrad Group. Internet: http://www.visegradgroup.eu/documents/bibliography/visegradarrival-survival-I20628 (accessed: I2.II.2OI5).

Wong, Reuben Y. (2005). The Europeanization of French Foreign Policy. France and the EU in East Asia, New York.
Wong, Reuben Y. (2007). Foreign Policy, in: Paolo Graziano/Maarten Vink (eds.): Europeanization: New Research Agendas, Basingstokes, 32 I-336.

\section{Author}

Dr. Patrick Müller is Ikerbasque Research Fellow at the Faculty for Social Science at the University of the Basque Country. From 2009 till 2015 he was Assistant Professor at the Institute for European Integration Research at Vienna University. Patrick was also working as Transatlantic Post-doc Fellow for International Relations at the German Institute for International and Security Affairs (SWP), the Institut Français des Relations Internationales (IFRI), Paris, and at the Johns Hopkins University in Washington DC. His research interests include Theories of International Relations, EU Foreign Policy, the role of the EU in global governance, European Policy toward the Middle East and the Mediterranean, and the Middle East conflict. 